\title{
PEMANFAATAN METODE AHP DALAM PEMILIHAN PROYEK INFRASTRUKTUR
}

\author{
Herri Suryadi Samosir, A. Perwira Mulia Tarigan dan Fahmi Fahmi \\ Universitas Sumatera Utara Medan, Indonesia \\ Email: medan.hss@yahoo.com, a.perwira@usu.ac.id dan fahmimn@usu.ac.id
}

\section{Abstract}

Public Private Partnership (PPP) in Indonesia is a KPBU (Collaboration between the Government and Businesses) in providing infrastructures for public utilities by referring to some specifications specified by the Minister/Heads of Institutions/ Heads of Regional Governments/State Own Enterprises/Regional Government Enterprises which partly and overall use business resources by sharing the risks. $K P B U$ can help the government develop infrastructures, but businesses usually get difficulty in investing their capital and to determine the projects they are going to choose. In general, the approach is only focused on capital recovery without considering other factors. This study explained the approaches which considered special criteria, knowledge of the infrastructures, and anything which is needed by the people. The criteria were assessed to organize PPP planning while Analytical Hierarchy Process (AHP) was used to complete the process of selecting multicriteria. The result of selecting and weighing multi-criteria could help determine the priority level of $K P B U$ projects.

Keywords: investment; infrastructure; KPBU; analytical hierarchy process (AHP); decision making
Abstrak
Public Private Partnership (PPP) di Indonesia dikenal sebagai Kerjasama Pemerintah dengan Badan Usaha (KPBU). KPBU didefinisikan sebagai Kerjasama antara Pemerintah dan Badan Usaha dalam penyediaan infrastruktur yang bertujuan untuk kepentingan umum dengan mengacu pada spesifikasi yang telah ditetapkan sebelumnya oleh Menteri/Kepala Lembaga/Kepala Daerah/Badan Usaha Milik Negara/Badan Usaha Milik Daerah (BUMN/BUMD), yang sebagian atau seluruhnya menggunakan sumber daya Badan Usaha dengan memperhatikan pembagian risiko di antara para pihak. KPBU dapat membantu pemerintah dalam pembangunan infrastruktur, namun sering kali badan usaha yang ingin berinvestasi mengalami kesulitan dalam menentukan proyek yang akan dipilih. Secara umum dalam berinvestasi pendekatannya hanya terfokus pada pengembalian modal dan tidak mempertimbangkan faktor-faktor lainnya. Studi ini menjelaskan pendekatan yang mempertimbangkan kriteria-kriteria khusus, pengetahuan tentang infrastruktur tersebut, dan permasalahan kebutuhan yang dirasakan di masyarakat. Dalam pendekatan ini digunakan penilaian kriteria untuk penyusunan rencana KPBU (PPP Planning). Proses Analytical Hierarchy Process (AHP) digunakan untuk menyelesaikan proses pemilihan dan pembobotan multi kriteria. Hasil analisa dari

$\begin{array}{ll}\text { How to cite: } & \text { Samosir, Herri Suryadi., A. Perwira Mulia Tarigan dan Fahmi Fahmi (2021). Pemanfaatan Metode } \\ & \text { AHP Dalam Pemilihan Proyek Infrastruktur. Syntax Literate. 6(5). http://dx.doi.org/10.36418/syntax- } \\ & \text { literate.v6i5.1265 } \\ \text { E-ISSN: } & 2548-1398 \\ \text { Published by: } & \text { Ridwan Institute }\end{array}$


pemilihan dan pembobotan multi kriteria dapat membantu dalam menentukan tingkat prioritas proyek KPBU.

Kata Kunci: investasi; infrastruktur; KPBU; analytical hierarchy process (AHP); pengambilan keputusan.

\section{Pendahuluan}

Di indonesia PPP dikenal sebagai Kerjasama Pemerintah dengan Badan Usaha (KPBU), KPBU didefinisikan sebagai kerjasama antara Pemerintah dan Badan Usaha dalam Penyediaan Infrastruktur bertujuan untuk kepentingan umum dengan mengacu pada spesifikasi yang telah ditetapkan sebelumnya oleh Menteri/Kepala Lembaga/Kepala Daerah/BUMN/BUMD, yang sebagian atau seluruhnya menggunakan sumber daya Badan Usaha dengan memperhatikan pembagian risiko diantara para pihak" (Samosir, 2020). Pertumbuhan ekonomi memerlukan infrastruktur yang memadai, celebrates anggaran dari pemerintah memberikan peluang pembiayaan proyek infrastruktur dilakukan dengan skema KPBU, hal ini membuat para stakeholder perlu untuk memilih prioritas proyek yang sesuai dengan tepat dan akurat. Stakehoder harus memiliki metode pengambilan keputusan untuk mendapatkan proyek dengan risiko yang sangat minimal dan sesuai dengan kebutuhan masyarakat. Indonesia menempati peringkat ke 36 dari 137 negara dengan score 4,68 pada skala score best 1-7 terkait buruknya fasilitas infrastruktur dan hal mengurangi daya tarik investasi masuk (Schwab, 2018). Proyek infrastruktur seperti proyek konstruksi lainnya adalah suatu hal yang kompleks dan penuh dengan ketidakpastian serta memiliki permasalahan yang bervariasi, kriteria suatu proyek dengan yang lain bisa berbeda dan hal tersebut harus dipertimbangkan dalam proses pengambilan keputusan dalam menentukan tingkat prioritas proyek, keputusan menjadi lebih sulit karena subjektivitas dalam penilaian dipengaruhi oleh perbedaan latarbelakang para stakeholder.

Terdapat beberapa cara atau metode dalam menilai, menganalisa risiko dan kelayakan suatu proyek, umumnya metode yang digunakan disesuaikan dengan pengalaman dalam menangani proyek sejenis. Sangat jarang menghitung kriteria dan risiko apa saja yang mempengaruhi proyek secara keseluruhan, hal ini kemungkinan disebabkan oleh kurangnya pendekatan yang langsung menggabungkan seluruh aspek risiko secara sistematis dalam suatu skema prioritas. Tingkat kompleksitas yang beragam dapat terjadi disebabkan perbedaan jenis proyek dan perbedaan jenis kriteria membuat metode yang umum digunakan tidak dapat memberikan penilaian yang sistematis, bahkan sering mengalami kegagalan dalam mengantisipasi risiko pada proyek, dari permasalahan yang terjadi tersebut maka sangat diperlukan suatu metode penilaian risiko yang sistematis dan rasional. Analytical Hierarchy Process (AHP) adalah metode pengambilan keputusan yang dapat dipergunakan untuk mengatasi permasalahan multi kriteria dan multi proyek (Saaty, 2008). Pengambilan keputusan metode AHP dilakukan dengan pendekatan dan penyusunan kriteria kedalam hiraki, menilai tingkat kepentingan suatu kriteria, membandingkan alternatif setiap kriteria, dan menentukan peringkat seluruh alternatif. Metode ini didasarkan oleh penilaian 
berdasarkan keahlian dan perhitungan matematis. Cara ini terbukti efektif dalam memecahkan masalah pengambilan keputusan yang sangat kompleks dan sangat membantu dalam mengidentifikasikan dan menseleksi kriteria, melakukan analisa terhadap data yang dikumpulkan untuk kriteria dan mempercepat proses dalam pengambilan keputusan. AHP sangat membantu dalam pengambilan keputusan yang kompleks dan tidak terstruktur.

Kelebihan yang terutama dalam penggunaan AHP adalah dapat melakukan evaluasi secara subjektif dan objektif, adanya perangkat yang dapat memeriksa konsistensi penilaian atau alternatif yang diberikan oleh ahli, sehingga dapat mengurangi subjektifias dalam pengambilan keputusan. Hal ini dapat membantu untuk mengurangi kekeliuran yang umum ditemui dalam proses pengambilan keputusan, seperti kurangnya pemahaman tentang kebutuhan keuangan, jangka waktu pengembalian, sistem kontrak dan risiko, yang pada akhirnya membuat pengambil keputusan sulit untuk menentukan pilihan yang tepat. Penggunaan AHP akan sangat membantu untuk mengambil keputusan yang tidak hanya didasarkan pada pengalaman, intuisi atau metode praktis tetapi juga melibatkan analisa kuantitatif dari kriteria dan pertimbangan seluruh faktor secara menyeluruh. Para pengambil keputusan akan terbantu dengan dilibatkannya orang-orang yang berpengalaman dan ahli dari multi disiplin dalam proses pengambilan keputusan, keterlibatan para ahli dibidangnya masing-masing sangat membantu untuk membuat keputusan yang lebih objektif dan tepat dengan adanya acuan alokasi risiko.

Referensi dari peneliti terdahulu "An AHP-based Construction Project Selection Method" (Nandi, Paul, \& Phadtare, 2011) yaitu memanfaatkan metode pengambilan keputusan AHP untuk menentukan pilihan terbaik dari beberapa opsi yang ada, pada penelitian pertama fokus penelitian adalah bagaimana kontraktor memilih proyek yang menguntungkan untuk dilaksanakan dari tiga pilihan yaitu proyek Thermal Power Project, Road Project dan Hydro Power Project dan pada penelitian kedua adalah "Implementing AHP Approach to Select an Appropriate Financing Method for PPP Highway Projects in Iran" (Noorzai, Jafari, Heshmatnezhad, \& Vahedi, 2016) bagaimana menentukan kontrak yang terbaik untuk pembangunan jalan di antara empat kontrak yaitu Traditional Private Outsourcing Contracts, Build- Operate- Transfer (BOT), Concessions Contracts (DBFO), Private Divestiture Contracts (BOO) (Delmon, 2010), penelitiaan yang pertama adalah penelitian yang memiliki persamaan dengan penelitian ini tetapi dengan perbedaan bahwa pengambil keputusan bukanlah kontraktor tetapi investor dan pemerintah, hal ini karena pelaksanaan proyek dilakukan dengan skema KPBU, dalam penelitian ini terdapat lima proyek yang akan ditentukan rangking prioritasnya yaitu proyek Rumah Sakit, SPAM, LRT, BRT dan TOL. Kontraktor di dalam menentukan kriteria dan sub kriteria lebih cenderung kepada investasi jangka pendek dan ini sangat berbeda dengan konsep KPBU yang lebih cenderung pada investasi jangka panjang di mana risiko kegagalan lebih tinggi, konsep pelaksanaan proyek KPBU sangat tergantung kepada pembagian risiko antara pemerintah dengan badan usaha, di mana badan usaha memiliki risiko lebih besar. 
Metode AHP sangat tergantung kepada penilaian ahli, oleh karenanya dalam penelitian ini sangat penting melakukan kuesioner langsung dari narasumber, investor dan pemerintah dalam penelitian ini adalah narasumber utama yang mutlak harus diperoleh, di samping narasumber yang lain seperti dari akademisi dan dari masyarakat sebagai pengguna jasa. Peran narasumber utama bukan hanya dalam menetapkan dan menilai perbandingan kepentingan kriteria dan sub kriterianya tetapi juga menilai hubungan dan pengaruh kriteria maupun sub kriteria terhadap masing-masing proyek, hasil kuesioner dari penilaian tingkat kepentingan masing-masing sub kriteria terhadap kriterianya disebut Daftar Peringkat Kriteria dan Sub Kriteria, adapun hasil kuesioner penilaian hubungan dan pengaruh kriteria maupun sub kriteria terhadap masing-masing proyek disebut Detail Masing-Masing Proyek.

\section{Metode Penelitian}

Penelitian ini menggunakan metode Analytical Hierarchy Process (AHP) (Sasongko, Astuti, \& Maharani, 2017), AHP dimanfaatkan untuk menentukan proyek infrastruktur prioritas yang dibutuhkan oleh masyarakat. Studi ini adalah untuk menentukan rangking prioritas dari tiga proyek infrastruktur yang akan dilaksanakan dengan skema KPBU.

Konsep dasar Analytical Hierarchy Process (AHP) adalah penggunaan matriks pairwise comparison (matriks perbandingan berpasangan) untuk menghasilkan bobot relatif antara kriteria maupun alternative (Darmanto, Latifah, \& Susanti, 2014). Suatu kriteria akan dibandingkan dengan kriteria lainnya dalam hal seberapa penting terhadap pencapaian tujuan di atasnya (Saaty, 1986). Konsep dasar AHP dapat dilihat pada Tabel 1 dan pada Gambar 2 dijelaskan mengenai struktur AHP.

\section{Tabel 1}

Konsep Dasar Analytical Hierarchy Process (AHP)

\begin{tabular}{ccl}
\hline $\begin{array}{c}\text { Tingkat } \\
\text { Kepentingan }\end{array}$ & Definisi & \multicolumn{1}{c}{ Keterangan } \\
\hline 1 & $\begin{array}{c}\text { Sama } \\
\text { Pentingnya }\end{array}$ & Kedua elemen mempunyai pengaruh yang sama \\
\hline 3 & $\begin{array}{c}\text { Sedikit Lebih } \\
\text { Penting }\end{array}$ & $\begin{array}{l}\text { Pengalaman dan penilaian sangat memihak satu elemen } \\
\text { dibandingkan dengan pasangannya }\end{array}$ \\
\hline 5 & Lebih Penting & $\begin{array}{l}\text { Satu elemen sangat disukai dan secara praktis dominasinya } \\
\text { sangat nyata, dibandingkan dengan elemen pasangannya }\end{array}$ \\
\hline 7 & Sangat Penting & $\begin{array}{l}\text { Satu elemen terbukti sangat disukai dan secara praktis } \\
\text { dominasinya sangat nyata, dibandingkan dengan elemen } \\
\text { pasangannya }\end{array}$ \\
\hline 9 & $\begin{array}{c}\text { Mutlak Lebih } \\
\text { Penting }\end{array}$ & $\begin{array}{l}\text { Satu elemen terbukti mutlak lebih disukai dibandingkan } \\
\text { dengan elemen pasangannya, pada keyakinan tertinggi }\end{array}$ \\
\hline $2,4,6,8$ & Nilai Tengah & $\begin{array}{l}\text { Diberikan bila terdapat keraguan penilaian di antara dua } \\
\text { tingkat kepentingan yang berdekatan }\end{array}$ \\
\hline Sumber $:($ Saty
\end{tabular}

Sumber : (Saaty, 1986) 


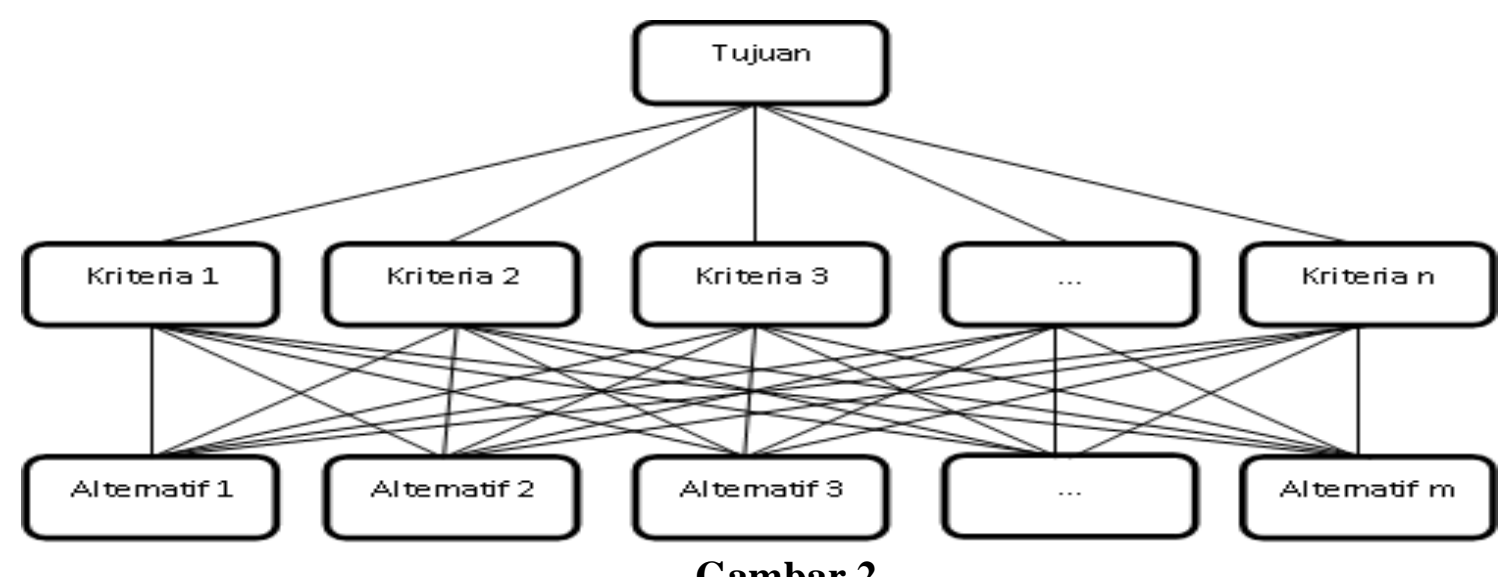

Gambar 2

Struktur Hierarki Analytical Hierarchy Process (AHP)

Matriks berpasangan antara dua elemen disusun dalam rumus:

$$
A=\left(\begin{array}{ccc}
a_{11} & \ldots & a_{1 n} \\
\ldots & \ldots & \ldots \\
a_{n 1} & \ldots & a_{n n}
\end{array}\right)=\left(\begin{array}{ccc}
w_{1} / w_{1} & \ldots & w_{1} / w_{n} \\
\ldots & \ldots & \ldots \\
w_{n} / w_{1} & \ldots & w_{n} / w_{n}
\end{array}\right)
$$

Kemudian menghitung konsistensi matriks dengan rumus:

$$
A=\left(\begin{array}{ccc}
w_{1} / w_{1} & \ldots & w_{1} / w_{n} \\
\ldots & \ldots & \ldots \\
w_{n} / w_{1} & \ldots & w_{n} / w_{n}
\end{array}\right) x\left[\begin{array}{c}
w_{1} \\
\ldots \\
w_{n}
\end{array}\right]=n\left[\begin{array}{c}
w_{1} \\
\ldots \\
w_{n}
\end{array}\right]
$$

Penilaian dalam membandingkan antara satu kriteria dengan kriteria yang lain di mana kriteria tersebut adalah bebas satu sama lain, dan hal ini dapat mengarah pada ketidak konsistensian. Dalam (Saaty, 1990), Indeks konsistensi dari matriks ber ordo " $n$ " dapat diperoleh dengan rumus:

CI $=(\lambda$ maks-n $) /(n-1)$.

Di mana :

$\lambda$ maks $=$ Nilai eigen terbesar dari matriks ber ordo $n$

Nilai eigen terbesar didapat dengan menjumlahkan hasil perkalian jumlah kolom dengan eigen vector. Batas ketidak konsistensian di ukur dengan menggunakan rasio konsistensi (CR), yakni perbandingan indeks konsistensi (CI) dengan nilai pembangkit random (RI). Nilai ini bergantung pada ordo matriks $n$.

Rasio konsistensi dapat dirumuskan :

$\mathrm{CR} \quad=\mathrm{CI} / \mathrm{RI}$.

CI = Indeks Konsistensi (Consistency Index)

$\mathrm{CR} \quad=$ Ratio Konsistensi (Consistency Ratio)

RI = Pembangkit Random (Random Index)

Bila nilai CR lebih kecil dari $10 \%$, ketidak konsistensian pendapat masih dianggap dapat diterima, daftar indeks random konsistensi (RI) dapat dilihat pada Tabel 2. 
Tabel 2

Daftar Index Random consistency (RI)

\begin{tabular}{ccccccccc}
\hline $\mathrm{n}$ & 1 & 2 & 3 & 4 & 5 & 6 & 7 & 8 \\
\hline $\mathrm{RI}$ & 0,0000 & 0,0000 & 0,5799 & 0,8921 & 1,1159 & 1,2358 & 1,3322 & 1,3952 \\
\hline $\mathrm{n}$ & 9 & 10 & 11 & 12 & 13 & 14 & 15 & \\
\hline $\mathrm{RI}$ & 1,4537 & 1,4882 & 1,5117 & 1,5356 & 1,5571 & 1,5714 & 1,5831 & \\
\hline
\end{tabular}

Sumber: Tummala and Ling (1998)

Langkah awal dalam penelitian ini adalah menetapkan kriteria utama dan sub kriteria dibawahnya, dari literatur sangat sedikit didapatkan informasi tentang pembiayaan proyek infrastruktur dengan skema KPBU yang menggunakan AHP, oleh karena hal tersebut maka penelitian ini dilakukan dengan metode wawancara dan Focus Group Discussion (FGD) yang dan menghasilkan 10 kriteria utama dan 36 sub kriteria (Afiyanti, 2008).

Langkah selanjutnya dari penelitian ini adalah melakukam penilaian terhadap seluruh sub kriteria dengan pendekatan kepada perusahaan pengembang untuk melakukan pemeringkatan sub kriteria pada skala 1-10 poin ditunjukkan pada Tabel 3.

Tabel 3

Daftar Peringkat Kriteria Utama dan Sub Kriteria

\begin{tabular}{|c|c|c|}
\hline 1 & Kriteria Keuangan $(\mathrm{KU})$ & \\
\hline & a $\quad$ Biaya investasi & 7 \\
\hline & Rasio minimal modal & 7 \\
\hline & Periode pengembalian (payback period) & 9 \\
\hline & d Index profitabilitas/Harga & 9 \\
\hline \multirow[t]{4}{*}{2} & Kriteria Teknis $($ TK) & \\
\hline & a Akses ke peralatan yang diperlukan & 9 \\
\hline & Mampu menerapkan teknologi baru & 8 \\
\hline & Kemudahan teknologi dalam pemeliharaan dan perbaikan & 7 \\
\hline \multirow[t]{4}{*}{3} & Kriteria Sumber Daya $(S D)$ & \\
\hline & a $\quad$ Kemampuan menyediakan sumber daya manusia & 9 \\
\hline & b Kemampuan menyediakan bahan/material pada masa konstruksi dan operasi & 7 \\
\hline & c Kemampuan menyediakan peralatan pada masa konstruksi dan operasi & 9 \\
\hline \multirow[t]{5}{*}{4} & Kriteria Kebijakan Pemerintah $(K P)$ & \\
\hline & a $\quad$ Bebas pajak PPN & 7 \\
\hline & b $\quad$ Subsidi BBM dan listrik & 7 \\
\hline & Dukungan dana konstruksi dari pemerintah (VGF) & 9 \\
\hline & d Dukungan sumberdaya dari pemerintah & 7 \\
\hline \multirow[t]{4}{*}{5} & Kriteria Klausal Kontrak $(K K)$ & \\
\hline & a $\quad$ Bonus dan penalty & 8 \\
\hline & b Garansi konstruksi dan peralatan & 8 \\
\hline & c Keadaan Kahar (Force Majeure) & 9 \\
\hline \multirow[t]{5}{*}{6} & Kriteria Lokasi $(\mathrm{LO})$ & \\
\hline & a $\quad$ Risiko pembebasan lahan & 7 \\
\hline & b Risiko ketidaksesuaian lokasi lahan & 7 \\
\hline & Risiko lingkungan & 9 \\
\hline & d Risiko terkait lokasi yang tak terduga & 9 \\
\hline 7 & Kriteria Desain $(D N)$ & \\
\hline
\end{tabular}


Herri Suryadi Samosir, A. Perwira Mulia Tarigan dan Fahmi Fahmi

\begin{tabular}{|c|c|c|}
\hline & Risiko perencanaan & 7 \\
\hline & Risiko desain & 9 \\
\hline & c Risiko penyelesaian & 9 \\
\hline & Risiko kenaikan biaya & 9 \\
\hline & e Risiko uji operasi & 8 \\
\hline 8 & \multicolumn{2}{|l|}{ Kriteria Finansial $(F L)$} \\
\hline & a Risiko ketidakpastian pembiayaan & 7 \\
\hline & b $\quad$ Risiko parameter finansial & 9 \\
\hline & Risiko struktur finansial & 8 \\
\hline & d $\quad$ Risiko asuransi & 7 \\
\hline \multicolumn{3}{|c|}{$9 \quad$ Kriteria Faktor Politik (FP) } \\
\hline & a Dukungan legislatif & 8 \\
\hline & Dukungan eksekutif & 8 \\
\hline & c $\quad$ Stabilitas politik & 8 \\
\hline \multicolumn{3}{|c|}{$10 \quad$ Kriteria Tujuan Proyek $(T P)$} \\
\hline & a $\quad$ Nilai prestise dalam perspektif publik & 7 \\
\hline & $\mathrm{b} \quad$ Epek pengganda & 9 \\
\hline & c Menarik investor & 8 \\
\hline
\end{tabular}

Setelah pemeringkatan selesai maka selanjutnya melakukan perbandingan berpasangan terhadap kriteria utama ditunjukkan pada Tabel 4 .

Tabel 4

Matriks Perbandingan Berpasangan Kriteria Utama

\begin{tabular}{ccccccccccc}
\hline $\mathrm{K}=\mathrm{n}$ & $\mathrm{KU}$ & $\mathrm{TK}$ & $\mathrm{SD}$ & $\mathrm{KP}$ & $\mathrm{KK}$ & $\mathrm{LO}$ & $\mathrm{DN}$ & FL & FP & TP \\
\hline $\mathrm{KU}$ & 1,00 & 1,00 & 1,00 & 1,00 & 2,00 & 0,50 & 3,00 & 0,33 & 1,00 & 0,50 \\
\hline $\mathrm{TK}$ & 1,00 & 1,00 & 1,00 & 1,00 & 3,00 & 1,00 & 1,00 & 1,00 & 1,00 & 0,33 \\
\hline $\mathrm{SD}$ & 1,00 & 1,00 & 1,00 & 1,00 & 3,00 & 1,00 & 2,00 & 0,20 & 3,00 & 0,50 \\
\hline $\mathrm{KP}$ & 1,00 & 1,00 & 1,00 & 1,00 & 3,00 & 3,00 & 1,00 & 0,50 & 1,00 & 2,00 \\
\hline KK & 0,50 & 0,33 & 0,33 & 0,33 & 1,00 & 0,33 & 1,00 & 0,14 & 1,00 & 0,33 \\
\hline LO & 2,00 & 1,00 & 1,00 & 0,33 & 3,00 & 1,00 & 2,00 & 0,50 & 2,00 & 2,00 \\
\hline DN & 0,33 & 1,00 & 0,50 & 1,00 & 1,00 & 0,50 & 1,00 & 0,33 & 1,00 & 0,50 \\
\hline FL & 3,00 & 1,00 & 5,00 & 2,00 & 7,00 & 2,00 & 3,00 & 1,00 & 5,00 & 5,00 \\
\hline FP & 1,00 & 1,00 & 0,33 & 1,00 & 1,00 & 0,50 & 1,00 & 0,20 & 1,00 & 0,33 \\
\hline TP & 2,00 & 3,00 & 2,00 & 0,50 & 3,00 & 0,50 & 2,00 & 0,20 & 3,00 & 1,00 \\
\hline Nilai & 12,83 & 11,33 & 13,17 & 9,17 & 27,00 & 10,33 & 17,00 & 4,41 & 19,00 & 12,50 \\
\hline
\end{tabular}

Melakukan sintesis prioritas untuk menghitung nilai eigen vektor matriks ditunjukkan pada Tabel 5.

Tabel 5

Nilai Eigen Vektor Matriks Kriteria Utama

\begin{tabular}{cccccc}
\hline \multicolumn{6}{c}{$\mathrm{NVP}=$ Nilai Vektor Prioritas Kriteria $\left(\sum \mathrm{NK} /\left(\sum \mathrm{K}=\mathrm{n}\right)\right)$} \\
\hline Nilai Prioritas Kriteria & $\mathrm{KU}$ & $\sum \mathrm{NK}$ & $\sum \mathrm{K}=\mathrm{n}$ & $\mathrm{NVP}$ & Bobot \\
\hline Nilai Prioritas Kriteria & $\mathrm{TK}$ & 0,92 & 10 & 0,08 & $8,18 \%$ \\
\hline Nilai Prioritas Kriteria & $\mathrm{SD}$ & 0,92 & 10 & 0,09 & $9,24 \%$ \\
\hline Nilai Prioritas Kriteria & $\mathrm{KP}$ & 1,14 & 10 & 0,09 & $9,20 \%$ \\
\hline Nilai Prioritas Kriteria & KK & 0,37 & 10 & 0,11 & $11,37 \%$ \\
\hline Nilai Prioritas Kriteria & LO & 1,06 & 10 & 0,11 & $3,70 \%$ \\
\hline
\end{tabular}




\begin{tabular}{cccccc}
\hline Nilai Prioritas Kriteria & DN & 0,57 & 10 & 0,06 & $5,74 \%$ \\
\hline Nilai Prioritas Kriteria & FL & 2,44 & 10 & 0,24 & $24,39 \%$ \\
\hline Nilai Prioritas Kriteria & FP & 0,57 & 10 & 0,06 & $5,69 \%$ \\
\hline Nilai Prioritas Kriteria & TP & 1,19 & 10 & 0,12 & $11,87 \%$ \\
\hline & & & & 1,00 & $100 \%$ \\
\hline
\end{tabular}

Setelah diperoleh nilai $\lambda \max$, maka selanjutnya dihitung nilai concistency ratio index $(\mathrm{CI})$ dan menghitung nilai concistency ratio $(\mathrm{CR})$ dengan menggunakan nilai random consistency $(\mathrm{RI})$ untuk $\mathrm{n}=10$ nilai RI diambil dari Tabel 2.2, perhitungan CI dan CR adalah sebagai berikut:

$$
\begin{aligned}
& \mathrm{CI}=(\lambda \text { maks }-\mathrm{n}) / \mathrm{n}-1 \\
& \mathrm{CI}=\frac{10,961-10}{10-1}=0,107 \\
& \text { Random Consistency }(\mathrm{RI})=1,557 \\
& \mathrm{CR}=\mathrm{CI} / \mathrm{RI} \\
& \mathrm{CR}=\frac{0,107}{1,557}=0,069
\end{aligned}
$$

Karena CR $<0,100$ preferensi pembobotan adalah konsisten

Selanjutnya mencari nilai $\lambda$ maks untuk mendapatkan nilai CI dan menghitung nilai CR untuk menetapkan konsistensi data. Proses yang sama dilakukan untuk seluruh sub kriteria dibawah kriteria utama, contoh matriks perbandingan berpasangan untuk sub kriteria dibawah salah satu kriteria utama “Teknis" yang terdiri dari 3 sub kriteria ditunjukkan pada Tabel 6 dan 7.

Tabel 6

Matriks Perbandingan Berpasangan Sub Kriteria dibawah Kriteria Teknik

\begin{tabular}{cccc}
\hline $\mathrm{K}=\mathrm{n}$ & $\mathrm{a}$ & $\mathrm{b}$ & $\mathrm{c}$ \\
\hline $\mathrm{a}$ & 1,00 & 2,00 & 1,00 \\
\hline $\mathrm{b}$ & 0,50 & 1,00 & 1,00 \\
\hline $\mathrm{c}$ & 1,00 & 1,00 & 1,00 \\
\hline Nilai & 2,50 & 4,00 & 3,00 \\
\hline
\end{tabular}

Tabel 7

Nilai Eigen Vektor Matriks Sub Kriteria dibawah Kriteria Teknik

\begin{tabular}{lccccc}
\hline \multicolumn{5}{c}{$\mathrm{NVP}=$ Nilai } & \multicolumn{5}{c}{ Vektor Prioritas Kriteria $\left(\sum \mathrm{NK} /\left(\sum \mathrm{K}=\mathrm{n}\right)\right)$} \\
\hline & & $\sum \mathrm{NK}$ & $\sum \mathrm{K}=\mathrm{n}$ & $\mathrm{NVP}$ & Bobot \\
Nilai Prioritas Kriteria & a & 1,23 & 3 & 0,41 & $41,11 \%$ \\
Nilai Prioritas Kriteria & b & 0,78 & 3 & 0,26 & $26,11 \%$ \\
Nilai Prioritas Kriteria & c & 0,98 & 3 & 0,33 & $32,78 \%$ \\
\hline
\end{tabular}

Setelah diperoleh nilai $\lambda \max$, maka selanjutnya dihitung nilai concistency ratio 
index (CI) dan menghitung nilai concistency ratio (CR) dengan menggunakan nilai random consistency $(\mathrm{RI})$ untuk $\mathrm{n}=3$ nilai RI diambil dari lihat Tabel 2, perhitungan $\mathrm{CI}$ dan CR adalah sebagai berikut:

$$
\begin{aligned}
\mathrm{CI}=(\lambda \text { maks }-\mathrm{n}) / \mathrm{n}-1 & \\
\mathrm{CI}=\frac{3,054-3}{3-1} & =0,027 \\
& =0,580
\end{aligned}
$$

Random Consistency (RI)

$$
\begin{aligned}
\mathrm{CR} & =\mathrm{CI} / \mathrm{RI} \\
\mathrm{CR} & =\frac{0,027}{0,580}=0,046
\end{aligned}
$$

Karena CR $<0,100$ preferensi pembobotan adalah konsisten

Detail proyek yang diteliti sebanyak 5 proyek infrastruktur tetapi bukan proyek yang nyata, yaitu Proyek Rumah Sakit (RSK), Proyek Sistem Penyediaan Air

\begin{tabular}{|c|c|c|c|c|c|c|}
\hline 1 & Kriteria Keuangan $(\mathrm{KU})$ & RSK & SPAM & LRT & BRT & TOL \\
\hline & Biaya investasi (dalam rupiah) & $546 \mathrm{M}$ & $210 \mathrm{M}$ & $\begin{array}{c}6.000 \\
M\end{array}$ & $413 \mathrm{M}$ & $\begin{array}{c}1.604 \\
\mathrm{M}\end{array}$ \\
\hline & b Rasio minimal modal & $5 \%$ & $20 \%$ & $20 \%$ & $20 \%$ & $20 \%$ \\
\hline & c Periode pengembalian (payback period) & 10 thn & 25 thn & $\begin{array}{c}20 \\
\text { thn }\end{array}$ & 5 thn & $\begin{array}{c}10 \\
\text { thn }\end{array}$ \\
\hline & Index profitabilitas/Harga & $15 \%$ & $15 \%$ & $20 \%$ & $10 \%$ & $10 \%$ \\
\hline \multirow[t]{4}{*}{2} & Kriteria Teknis (TK) & & & & & \\
\hline & a $\quad$ Akses ke peralatan yang diperlukan & ya & ya & ya & ya & tidak \\
\hline & b Mampu menerapkan teknologi baru & ya & ya & уа & уа & tidak \\
\hline & $\begin{array}{l}\text { Kemudahan teknologi dalam pemeliharaan dan } \\
\text { perbaikan }\end{array}$ & ya & ya & ya & ya & tidak \\
\hline \multirow[t]{4}{*}{3} & Kriteria Sumber Daya $(S D)$ & & & & & \\
\hline & a $\quad$ Kemampuan menyediakan sumberdaya manusia & harus & harus & ya & ya & ya \\
\hline & b $\quad$ Kemampuan menyediakan bahan/material & harus & ya & ya & ya & ya \\
\hline & c $\quad$ Kemampuan menyediakan peralatan & harus & ya & ya & ya & ya \\
\hline \multirow[t]{5}{*}{4} & Kriteria Kebijakan Pemerintah $(K P)$ & & & & & \\
\hline & a Bebas pajak PPN & ya & tidak & tidak & tidak & tidak \\
\hline & $\begin{array}{ll}\mathrm{b} & \text { Subsidi BBM dan listrik } \\
\end{array}$ & ya & ya & tidak & tidak & tidak \\
\hline & c Dukungan dana konstruksi dari pemerintah (VGF) & ya & tidak & tidak & ya & tidak \\
\hline & d $\quad$ Dukungan sumberdaya dari pemerintah & ya & ya & ya & ya & ya \\
\hline \multirow[t]{4}{*}{5} & Kriteria Klausal Kontrak $(\mathrm{KK})$ & & & & & \\
\hline & a $\quad$ Bonus dan penalty & ya & ya & ya & ya & ya \\
\hline & Garansi konstruksi dan peralatan & ya & ya & ya & ya & ya \\
\hline & $\begin{array}{ll}\text { c } & \text { Keadaan Kahar (Force Majeure) }\end{array}$ & ya & ya & ya & ya & ya \\
\hline \multirow[t]{3}{*}{6} & Kriteria Lokasi $(\mathrm{LO})$ & & & & & \\
\hline & a Risiko pembebasan lahan & sedang & rendah & tinggi & rendah & tinggi \\
\hline & b Risiko ketidaksesuaian lokasi lahan & rendah & sedang & tinggi & rendah & tinggi \\
\hline
\end{tabular}
Minum (SPAM), Proyek Light Rail Transit (LRT), Proyek Bus Rapit Transit (BRT) dan Proyek Tax On Location (TOL) ditunjukkan pada Tabel 8.

\section{Tabel 8}

Detail Proyek RSK-SPAM-LRT-BRT-TOL 


\begin{tabular}{|c|c|c|c|c|c|c|}
\hline & c Risiko lingkungan & tinggi & tinggi & sedang & rendah & tinggi \\
\hline & d Risiko terkait lokasi yang tak terduga & sedang & sedang & tinggi & rendah & tinngi \\
\hline \multirow[t]{6}{*}{7} & Kriteria Desain $(D N)$ & & & & & \\
\hline & a Risiko perencanaan & tinggi & rendah & sedang & sedang & sedang \\
\hline & b $\quad$ Risiko desain & sedang & tinggi & sedang & rendah & rendah \\
\hline & c Risiko penyelesaian & tidak & ya & ya & tidak & ya \\
\hline & d $\quad$ Risiko kenaikan biaya & sedang & rendah & tinggi & sedang & rendah \\
\hline & e $\quad$ Risiko uji operasi & sedang & tinggi & tinggi & rendah & tinggi \\
\hline \multirow[t]{5}{*}{8} & Kriteria Finansial $(F L)$ & & & & & \\
\hline & a Risiko ketidakpastian pembiayaan & tinggi & sedang & rendah & rendah & rendah \\
\hline & b Risiko parameter finansial & rendah & tinggi & tinggi & rendah & sedang \\
\hline & c Risiko struktur finansial & sedang & tinggi & tiunggi & rendah & sedang \\
\hline & d $\quad$ Risiko asuransi & rendah & sedang & tinggi & sedang & rendah \\
\hline \multirow[t]{4}{*}{9} & Kriteria Faktor Politik (FP) & & & & & \\
\hline & a $\quad$ Dukungan legislatif & rendah & timggi & tinggi & rendah & sedang \\
\hline & b $\quad$ Dukungan legislatif & tinggi & sedang & tinggi & rendah & sedang \\
\hline & $\begin{array}{ll}\text { c } & \text { Stabilitas Politik } \\
\end{array}$ & sedang & rendah & tinggi & sedang & tinggi \\
\hline \multirow[t]{4}{*}{10} & Kriteria Tujuan Proyek $(T P)$ & & & & & \\
\hline & a Nilai prestise dalam perspektif publik & sedang & rendah & tinggi & tinggi & tinggi \\
\hline & b $\quad$ Epek pengganda & sedang & rendah & tinggi & tinggi & tinggi \\
\hline & c Menarik investor & sedang & rendah & tinggi & tinggi & tinggi \\
\hline
\end{tabular}

Selanjutnya proses yang sama juga dilakukan untuk menghitung pengaruh dan bobot masing-masing proyek terhadap sub kriteria yang ditinjau, untuk contoh perhitungan diambil sub kriteria "a" (akses keperalatan yang diperlukan) dibawah kriteria utama “Teknik" seperti ditunjukkan pada Tabel 9 dan 10.

Tabel 9

Matriks Perbandingan Berpasangan Proyek

\begin{tabular}{cccccc}
\hline K=n & RSK & SPAM & LRT & BRT & TOL \\
RSK & 1,00 & 2,00 & 2,00 & 2,00 & 1,00 \\
SPAM & 0,50 & 1,00 & 3,00 & 3,00 & 3,00 \\
LRT & 0,50 & 0,33 & 1,00 & 2,00 & 2,00 \\
BRT & 0,50 & 0,33 & 0,50 & 1,00 & 1,00 \\
TOL & 1,00 & 0,33 & 0,50 & 1,00 & 1,00 \\
\hline Nilai & 3,50 & 4,00 & 7,00 & 9,00 & 8,00 \\
\hline
\end{tabular}

Tabel 10

Nilai Eigen Vektor Matriks Proyek

\begin{tabular}{llcccc}
\hline \multicolumn{6}{c}{$\mathrm{NVP}=$ Nilai Vektor Prioritas Kriteria $\left(\sum \mathrm{NK} /\left(\sum \mathrm{K}=\mathrm{n}\right)\right)$} \\
\hline Nilai Prioritas Kriteria & RSK & $\sum \mathrm{NK}$ & $\sum \mathrm{K}=\mathrm{n}$ & $\mathrm{NVP}$ & Bobot \\
Nilai Prioritas Kriteria & SPAM & 1,53 & 5 & 0,28 & $28,37 \%$ \\
Nilai Prioritas Kriteria & LRT & 0,84 & 5 & 0,31 & $30,60 \%$ \\
Nilai Prioritas Kriteria & BRT & 0,53 & 5 & 0,17 & $16,83 \%$ \\
Nilai Prioritas Kriteria & TOL & 0,68 & 5 & 0,11 & $10,67 \%$ \\
\hline \multicolumn{7}{l}{}
\end{tabular}

Setelah diperoleh nilai $\lambda \max$, maka selanjutnya dihitung nilai concistency ratio 
index (CI) dan menghitung nilai concistency ratio (CR) dengan menggunakan nilai random consistency (RI) untuk $\mathrm{n}=5$ nilai RI diambil dari lihat Tabel 2, perhitungan CI dan $\mathrm{CR}$ adalah sebagai berikut :

$$
\begin{aligned}
& \mathrm{CI}=(\lambda \text { maks }-\mathrm{n}) / \mathrm{n}-1 \\
& \mathrm{CI}=\frac{5,397}{5}-\frac{5}{-}=0,099 \\
& \text { Random Consistency (RI) = } \quad 1,116 \\
& \mathrm{CR}=\mathrm{CI} / \mathrm{RI} \\
& \mathrm{CR}=\frac{0,099}{1,116}=0,089
\end{aligned}
$$

Karena CR $<0,100$ preferensi pembobotan adalah konsisten

Tingkat prioritas proyek dihasilkan dari penjumlahan hasil perkalian bobot kriteria utama dengan bobot sub kriteria dan bobot masing-masing proyek terhadap

\begin{tabular}{|c|c|c|c|c|c|c|}
\hline No & Kriteria & $\begin{array}{c}\text { Sub } \\
\text { Kriteria }\end{array}$ & $\begin{array}{c}\text { Nilai } \\
\text { Prioritas } \\
\text { Kriteria } \\
(\text { KR })\end{array}$ & $\begin{array}{c}\text { Nilai } \\
\text { Prioritas } \\
\text { Sub Kriteria } \\
\text { (SK) }\end{array}$ & $\begin{array}{c}\text { Proyek } \\
\text { Prioritas Sub } \\
\text { Kriteria } \\
\text { (P) }\end{array}$ & $\begin{array}{c}\text { Prioritas (PR) } \\
= \\
(\mathrm{KR}) \times(\mathbf{S K}) \times(\mathrm{P})\end{array}$ \\
\hline 1 & KU & $a$ & 0,082 & 0,329 & 0,338 & 0,009 \\
\hline 2 & & $\mathrm{~b}$ & 0,082 & 0,329 & 0,303 & 0,008 \\
\hline 3 & & $\mathrm{c}$ & 0,082 & 0,200 & 0,353 & 0,006 \\
\hline 4 & & $\mathrm{~d}$ & 0,082 & 0,142 & 0,276 & 0,003 \\
\hline 5 & TK & $\mathrm{a}$ & 0,092 & 0,411 & 0,284 & 0,011 \\
\hline 6 & & $\mathrm{~b}$ & 0,092 & 0,261 & 0,286 & 0,007 \\
\hline 7 & & $\mathrm{c}$ & 0,092 & 0,328 & 0,286 & 0,009 \\
\hline 8 & SD & $\mathrm{a}$ & 0,092 & 0,411 & 0,230 & 0,009 \\
\hline 9 & & $\mathrm{~b}$ & 0,092 & 0,261 & 0,195 & 0,005 \\
\hline 10 & & $\mathrm{c}$ & 0,092 & 0,328 & 0,193 & 0,006 \\
\hline 11 & $\mathrm{KP}$ & $\mathrm{a}$ & 0,114 & 0,284 & 0,193 & 0,006 \\
\hline 12 & & $\mathrm{~b}$ & 0,114 & 0,284 & 0,193 & 0,006 \\
\hline 13 & & $\mathrm{c}$ & 0,114 & 0,217 & 0,259 & 0,006 \\
\hline 14 & & $\mathrm{~d}$ & 0,114 & 0,216 & 0,280 & 0,007 \\
\hline 15 & KK & $\mathrm{a}$ & 0,037 & 0,539 & 0,217 & 0,004 \\
\hline 16 & & $\mathrm{~b}$ & 0,037 & 0,297 & 0,276 & 0,003 \\
\hline 17 & & $\mathrm{c}$ & 0,037 & 0,164 & 0,300 & 0,002 \\
\hline 18 & LO & $\mathrm{a}$ & 0,106 & 0,338 & 0,281 & 0,010 \\
\hline 19 & & $\mathrm{~b}$ & 0,106 & 0,288 & 0,316 & 0,010 \\
\hline 20 & & $\mathrm{c}$ & 0,106 & 0,169 & 0,324 & 0,006 \\
\hline 21 & & $\mathrm{~d}$ & 0,106 & 0,205 & 0,311 & 0,007 \\
\hline 22 & DN & $a$ & 0,057 & 0,379 & 0,254 & 0,006 \\
\hline 23 & & $\mathrm{~b}$ & 0,057 & 0,268 & 0,285 & 0,004 \\
\hline 24 & & $\mathrm{c}$ & 0,057 & 0,149 & 0,311 & 0,003 \\
\hline 25 & & $\mathrm{~d}$ & 0,057 & 0,095 & 0,262 & 0,001 \\
\hline
\end{tabular}
seluruh sub kriteria, contoh proyek RSK, SPAM dan LRT seperti ditunjukan pada Tabel 11, 12 dan 13.

Tabel 11

Bobot Prioritas Proyek Rumah Sakit (RKS) 


\begin{tabular}{|c|c|c|c|c|c|c|}
\hline No & Kriteria & $\begin{array}{c}\text { Sub } \\
\text { Kriteria }\end{array}$ & $\begin{array}{c}\text { Nilai } \\
\text { Prioritas } \\
\text { Kriteria } \\
(\mathbf{K R}) \\
\end{array}$ & $\begin{array}{c}\text { Nilai } \\
\text { Prioritas } \\
\text { Sub Kriteria } \\
\text { (SK) }\end{array}$ & $\begin{array}{c}\text { Proyek } \\
\text { Prioritas Sub } \\
\text { Kriteria } \\
\text { (P) } \\
\end{array}$ & $\begin{array}{c}\text { Prioritas (PR) } \\
= \\
(\mathrm{KR}) \mathbf{( S K}) \mathbf{x}(\mathbf{P})\end{array}$ \\
\hline 26 & & $\mathrm{e}$ & 0,057 & 0,108 & 0,336 & 0,002 \\
\hline 27 & FL & $\mathrm{a}$ & 0,244 & 0,370 & 0,230 & 0,021 \\
\hline 28 & & $\mathrm{~b}$ & 0,244 & 0,221 & 0,328 & 0,018 \\
\hline 29 & & $\mathrm{c}$ & 0,244 & 0,171 & 0,324 & 0,014 \\
\hline 30 & & $\mathrm{~d}$ & 0,244 & 0,238 & 0,309 & 0,018 \\
\hline 31 & FP & $\mathrm{a}$ & 0,057 & 0,490 & 0,264 & 0,007 \\
\hline 32 & & $\mathrm{~b}$ & 0,057 & 0,312 & 0,336 & 0,006 \\
\hline 33 & & $\mathrm{c}$ & 0,057 & 0,198 & 0,284 & 0,003 \\
\hline 34 & $\mathrm{TP}$ & $\mathrm{a}$ & 0,119 & 0,548 & 0,255 & 0,017 \\
\hline 35 & & $\mathrm{~b}$ & 0,119 & 0,211 & 0,258 & 0,006 \\
\hline \multirow[t]{2}{*}{36} & & $\mathrm{c}$ & 0,119 & 0,241 & 0,259 & 0,007 \\
\hline & & Total Priori & $\sum(\mathrm{PR})=\mathrm{P}$ & ritas Proyek : & & 0,272 \\
\hline
\end{tabular}

Tabel 12

Bobot Prioritas Proyek SPAM

\begin{tabular}{|c|c|c|c|c|c|c|}
\hline No & Kriteria & $\underset{\text { Kriteria }}{\text { Sub }}$ & $\begin{array}{c}\text { Nilai } \\
\text { Prioritas } \\
\text { Kriteria } \\
(\text { KR) }\end{array}$ & $\begin{array}{c}\text { Nilai } \\
\text { Prioritas } \\
\text { Sub Kriteria } \\
\text { (SK) }\end{array}$ & $\begin{array}{l}\text { Proyek Prioritas } \\
\text { Sub Kriteria } \\
\text { (P) }\end{array}$ & $\begin{array}{c}\text { Prioritas (PR) } \\
= \\
(\mathrm{KR}) \mathbf{x}(\mathbf{S K}) \mathbf{x}(\mathbf{P})\end{array}$ \\
\hline 1 & KU & $\mathrm{a}$ & 0,082 & 0,329 & 0,378 & 0,010 \\
\hline 2 & & $\mathrm{~b}$ & 0,082 & 0,329 & 0,327 & 0,009 \\
\hline 3 & & $\mathrm{c}$ & 0,082 & 0,200 & 0,221 & 0,004 \\
\hline 4 & & $\mathrm{~d}$ & 0,082 & 0,142 & 0,288 & 0,003 \\
\hline 5 & TK & $\mathrm{a}$ & 0,092 & 0,411 & 0,306 & 0,012 \\
\hline 6 & & $\mathrm{~b}$ & 0,092 & 0,261 & 0,314 & 0,008 \\
\hline 7 & & $\mathrm{c}$ & 0,092 & 0,328 & 0,314 & 0,010 \\
\hline 8 & SD & $a$ & 0,092 & 0,411 & 0,300 & 0,011 \\
\hline 9 & & $\mathrm{~b}$ & 0,092 & 0,261 & 0,294 & 0,007 \\
\hline 10 & & $\mathrm{c}$ & 0,092 & 0,328 & 0,263 & 0,008 \\
\hline 11 & KP & $\mathrm{a}$ & 0,114 & 0,284 & 0,333 & 0,011 \\
\hline 12 & & $\mathrm{~b}$ & 0,114 & 0,284 & 0,333 & 0,011 \\
\hline 13 & & $\mathrm{c}$ & 0,114 & 0,217 & 0,297 & 0,007 \\
\hline 14 & & d & 0,114 & 0,216 & 0,302 & 0,007 \\
\hline 15 & KK & $\mathrm{a}$ & 0,037 & 0,539 & 0,329 & 0,007 \\
\hline 16 & & $\mathrm{~b}$ & 0,037 & 0,297 & 0,324 & 0,004 \\
\hline 17 & & $\mathrm{c}$ & 0,037 & 0,164 & 0,359 & 0,002 \\
\hline 18 & LO & $\mathrm{a}$ & 0,106 & 0,338 & 0,331 & 0,012 \\
\hline 19 & & $\mathrm{~b}$ & 0,106 & 0,288 & 0,327 & 0,010 \\
\hline 20 & & $\mathrm{c}$ & 0,106 & 0,169 & 0,288 & 0,005 \\
\hline 21 & & $\mathrm{~d}$ & 0,106 & 0,205 & 0,322 & 0,007 \\
\hline 22 & $\mathrm{DN}$ & $\mathrm{a}$ & 0,057 & 0,379 & 0,380 & 0,008 \\
\hline 23 & & b & 0,057 & 0,268 & 0,244 & 0,004 \\
\hline 24 & & $\mathrm{c}$ & 0,057 & 0,149 & 0,322 & 0,003 \\
\hline 25 & & $\mathrm{~d}$ & 0,057 & 0,095 & 0,334 & 0,002 \\
\hline 26 & & $\mathrm{e}$ & 0,057 & 0,108 & 0,281 & 0,002 \\
\hline 27 & FL & $\mathrm{a}$ & 0,244 & 0,370 & 0,300 & 0,027 \\
\hline 28 & & $\mathrm{~b}$ & 0,244 & 0,221 & 0,288 & 0,016 \\
\hline
\end{tabular}


Herri Suryadi Samosir, A. Perwira Mulia Tarigan dan Fahmi Fahmi

\begin{tabular}{|c|c|c|c|c|c|c|}
\hline No & Kriteria & $\underset{\text { Kriteria }}{\text { Sub }}$ & $\begin{array}{c}\text { Nilai } \\
\text { Prioritas } \\
\text { Kriteria } \\
(\text { KR })\end{array}$ & $\begin{array}{c}\text { Nilai } \\
\text { Prioritas } \\
\text { Sub Kriteria } \\
\text { (SK) }\end{array}$ & $\begin{array}{c}\text { Proyek Prioritas } \\
\text { Sub Kriteria } \\
\text { (P) }\end{array}$ & $\begin{array}{c}\text { Prioritas (PR) } \\
= \\
(\mathrm{KR}) \mathbf{x}(\mathrm{SK}) \mathbf{x}(\mathrm{P})\end{array}$ \\
\hline 29 & & c & 0,244 & 0,171 & 0,280 & 0,012 \\
\hline 30 & & $\mathrm{~d}$ & 0,244 & 0,238 & 0,298 & 0,017 \\
\hline 31 & FP & $\mathrm{a}$ & 0,057 & 0,490 & 0,346 & 0,010 \\
\hline 32 & & $\mathrm{~b}$ & 0,057 & 0,312 & 0,227 & 0,004 \\
\hline 33 & & $\mathrm{c}$ & 0,057 & 0,198 & 0,306 & 0,003 \\
\hline 34 & $\mathrm{TP}$ & $\mathrm{a}$ & 0,119 & 0,548 & 0,295 & 0,019 \\
\hline 35 & & $\mathrm{~b}$ & 0,119 & 0,211 & 0,295 & 0,007 \\
\hline \multirow[t]{2}{*}{36} & & $\mathrm{c}$ & 0,119 & 0,241 & 0,297 & 0,009 \\
\hline & & & Tota & ioritas $\sum(\mathrm{PR})$ & Prioritas Proyek : & 0,306 \\
\hline
\end{tabular}

Tabel 13

Bobot Prioritas Proyek LRT

\begin{tabular}{|c|c|c|c|c|c|c|}
\hline No & Kriteria & $\underset{\text { Kriteria }}{\text { Sub }}$ & $\begin{array}{c}\text { Nilai } \\
\text { Prioritas } \\
\text { Kriteria } \\
\text { (KR) } \\
\end{array}$ & $\begin{array}{c}\text { Nilai } \\
\text { Prioritas } \\
\text { Sub Kriteria } \\
\text { (SK) } \\
\end{array}$ & $\begin{array}{c}\text { Proyek Prioritas } \\
\text { Sub Kriteria } \\
\text { (P) }\end{array}$ & $\begin{array}{c}\text { Prioritas (PR) } \\
= \\
(\mathrm{KR}) \mathbf{x}(\mathrm{SK}) \mathbf{x}(\mathbf{P})\end{array}$ \\
\hline 1 & KU & $\mathrm{a}$ & 0,082 & 0,329 & 0,084 & 0,002 \\
\hline 2 & & b & 0,082 & 0,329 & 0,150 & 0,004 \\
\hline 3 & & $\mathrm{c}$ & 0,082 & 0,200 & 0,124 & 0,002 \\
\hline 4 & & $\mathrm{~d}$ & 0,082 & 0,142 & 0,117 & 0,001 \\
\hline 5 & TK & $\mathrm{a}$ & 0,092 & 0,411 & 0,168 & 0,006 \\
\hline 6 & & $\mathrm{~b}$ & 0,092 & 0,261 & 0,124 & 0,003 \\
\hline 7 & & $\mathrm{c}$ & 0,092 & 0,328 & 0,124 & 0,004 \\
\hline 8 & SD & $\mathrm{a}$ & 0,092 & 0,411 & 0,208 & 0,008 \\
\hline 9 & & $\mathrm{~b}$ & 0,092 & 0,261 & 0,167 & 0,004 \\
\hline 10 & & c & 0,092 & 0,328 & 0,168 & 0,005 \\
\hline 11 & KP & $\mathrm{a}$ & 0,114 & 0,284 & 0,212 & 0,007 \\
\hline 12 & & $\mathrm{~b}$ & 0,114 & 0,284 & 0,212 & 0,007 \\
\hline 13 & & $\mathrm{c}$ & 0,114 & 0,217 & 0,133 & 0,003 \\
\hline 14 & & $\mathrm{~d}$ & 0,114 & 0,216 & 0,140 & 0,003 \\
\hline 15 & KK & $\mathrm{a}$ & 0,037 & 0,539 & 0,210 & 0,004 \\
\hline 16 & & $\mathrm{~b}$ & 0,037 & 0,297 & 0,128 & 0,001 \\
\hline 17 & & $\mathrm{c}$ & 0,037 & 0,164 & 0,107 & 0,001 \\
\hline 18 & LO & $\mathrm{a}$ & 0,106 & 0,338 & 0,155 & 0,006 \\
\hline 19 & & $\mathrm{~b}$ & 0,106 & 0,288 & 0,107 & 0,003 \\
\hline 20 & & $\mathrm{c}$ & 0,106 & 0,169 & 0,121 & 0,002 \\
\hline 21 & & $\mathrm{~d}$ & 0,106 & 0,205 & 0,107 & 0,002 \\
\hline 22 & DN & $\mathrm{a}$ & 0,057 & 0,379 & 0,179 & 0,004 \\
\hline 23 & & $\mathrm{~b}$ & 0,057 & 0,268 & 0,140 & 0,002 \\
\hline 24 & & $\mathrm{c}$ & 0,057 & 0,149 & 0,107 & 0,001 \\
\hline 25 & & $\mathrm{~d}$ & 0,057 & 0,095 & 0,111 & 0,001 \\
\hline 26 & & $\mathrm{e}$ & 0,057 & 0,108 & 0,111 & 0,001 \\
\hline 27 & FL & $\mathrm{a}$ & 0,244 & 0,370 & 0,208 & 0,019 \\
\hline 28 & & $\mathrm{~b}$ & 0,244 & 0,221 & 0,110 & 0,006 \\
\hline 29 & & $\mathrm{c}$ & 0,244 & 0,171 & 0,113 & 0,005 \\
\hline 30 & & $\mathrm{~d}$ & 0,244 & 0,238 & 0,118 & 0,007 \\
\hline
\end{tabular}




\begin{tabular}{ccccccc}
\hline No & Kriteria & $\begin{array}{c}\text { Sub } \\
\text { Kriteria }\end{array}$ & $\begin{array}{c}\text { Nilai } \\
\text { Prioritas } \\
\text { Kriteria } \\
(\mathbf{K R})\end{array}$ & $\begin{array}{c}\text { Nilai } \\
\text { Prioritas } \\
\text { Sub Kriteria } \\
(\mathbf{S K})\end{array}$ & $\begin{array}{c}\text { Proyek Prioritas } \\
\text { Sub Kriteria } \\
(\mathbf{P})\end{array}$ & $\begin{array}{c}\text { Prioritas (PR) } \\
= \\
(\mathbf{K R}) \mathbf{x}(\mathbf{S K}) \mathbf{x}(\mathbf{P})\end{array}$ \\
\hline 31 & FP & a & 0,057 & 0,490 & 0,115 & 0,003 \\
\hline 32 & & b & 0,057 & 0,312 & 0,149 & 0,003 \\
\hline 33 & & c & 0,057 & 0,198 & 0,168 & 0,002 \\
\hline 34 & TP & a & 0,119 & 0,548 & 0,208 & 0,014 \\
\hline 35 & & b & 0,119 & 0,211 & 0,159 & 0,004 \\
\hline 36 & & c & 0,119 & 0,241 & 0,133 & 0,004 \\
\hline & & \multicolumn{2}{c}{ Total Prioritas $\sum(\mathrm{PR})=$ Prioritas Proyek : } & 0,153 \\
\hline
\end{tabular}

\section{Hasil dan Pembahasan}

Analisa selanjutnya adalah menetapkan rangking kriteria utama untuk masing-masing proyek ditunjukkan pada Tabel 14, 15, 16, 17 dan 18.

\section{Tabel 14}

\section{Daftar Rangking Kriteria untuk Proyek Rumah Sakit}

\begin{tabular}{ccc}
\hline Peringkat & Kriteria & Bobot \\
\hline Rangking 1 & Kriteria Finansial (FL) & $25,700 \%$ \\
\hline Rangking 2 & Kriteria Lokasi (LO) & $11,877 \%$ \\
\hline Rangking 3 & Kriteria Tujuan Proyek (TP) & $11,205 \%$ \\
\hline Rangking 4 & Kriteria Teknis (TK) & $9,676 \%$ \\
\hline Rangking 5 & Kriteria Keuangan (KU) & $9,648 \%$ \\
\hline Rangking 6 & Kriteria Kebijakan Pemerintah (KP) & $9,457 \%$ \\
\hline Rangking 7 & Kriteria Sumber Daya (SD) & $7,068 \%$ \\
\hline Rangking 8 & Kriteria Faktor Politik (FP) & $6,076 \%$ \\
\hline Rangking 9 & Kriteria Desain (DN) & $5,917 \%$ \\
\hline Rangking 10 & Kriteria Klausal Kontrak (KK) & $3,376 \%$ \\
\hline & Total: & $100,000 \%$ \\
\hline
\end{tabular}

\section{Tabel 15}

\section{Daftar Rangking Kriteria untuk Proyek SPAM}

\begin{tabular}{ccc}
\hline Peringkat & Kriteria & Bobot \\
\hline Rangking 1 & Kriteria Finansial (FL) & $23,420 \%$ \\
\hline Rangking 2 & Kriteria Kebijakan Pemerintah (KP) & $11,861 \%$ \\
\hline Rangking 3 & Kriteria Tujuan Proyek (TP) & $11,470 \%$ \\
\hline Rangking 4 & Kriteria Lokasi (LO) & $11,124 \%$ \\
\hline Rangking 5 & Kriteria Teknis (TK) & $9,395 \%$ \\
\hline Rangking 6 & Kriteria Sumber Daya (SD) & $8,613 \%$ \\
\hline Rangking 7 & Kriteria Keuangan (KU) & $8,487 \%$ \\
\hline Rangking 8 & Kriteria Desain (DN) & $6,000 \%$ \\
\hline Rangking 9 & Kriteria Faktor Politik (FP) & $5,610 \%$ \\
\hline Rangking 10 & Kriteria Klausal Kontrak (KK) & $4,021 \%$ \\
\hline & Total: & $100,000 \%$ \\
\hline
\end{tabular}




\section{Tabel 16}

Daftar Rangking Kriteria untuk Proyek LRT

\begin{tabular}{|c|c|c|}
\hline \multicolumn{3}{|c|}{ NILAI RANGKING KRITERIA } \\
\hline Peringkat & Kriteria & Bobot \\
\hline Rangking 1 & Kriteria Finansial (FL) & $23,677 \%$ \\
\hline Rangking 2 & Kriteria Tujuan Proyek (TP) & $13,922 \%$ \\
\hline Rangking 3 & Kriteria Kebijakan Pemerintah (KP) & $13,283 \%$ \\
\hline Rangking 4 & Kriteria Sumber Daya (SD) & $11,050 \%$ \\
\hline Rangking 5 & Kriteria Lokasi (LO) & $8,697 \%$ \\
\hline Rangking 6 & Kriteria Teknis (TK) & $8,554 \%$ \\
\hline Rangking 7 & Kriteria Keuangan (KU) & $6,307 \%$ \\
\hline Rangking 8 & Kriteria Desain (DN) & $5,377 \%$ \\
\hline Rangking 9 & Kriteria Faktor Politik (FP) & $5,061 \%$ \\
\hline Rangking 10 & Kriteria Klausal Kontrak (KK) & $4,072 \%$ \\
\hline & $\begin{aligned} \\
\text { To }\end{aligned}$ & $100,000 \%$ \\
\hline
\end{tabular}

\section{Tabel 17}

Daftar Rangking Kriteria untuk Proyek BRT

\begin{tabular}{ccr}
\hline & NILAI RANGKING KRITERIA & \\
\hline Peringkat & Kriteria & Bobot \\
\hline Rangking 1 & Kriteria Finansial (FL) & $23,677 \%$ \\
\hline Rangking 2 & Kriteria Tujuan Proyek (TP) & $13,922 \%$ \\
\hline Rangking 3 & Kriteria Kebijakan Pemerintah (KP) & $11,640 \%$ \\
\hline Rangking 4 & Kriteria Sumber Daya (SD) & $11,374 \%$ \\
\hline Rangking 5 & Kriteria Lokasi (LO) & $10,899 \%$ \\
\hline Rangking 6 & Kriteria Teknis (TK) & $7,492 \%$ \\
\hline Rangking 7 & Kriteria Keuangan (KU) & $7,252 \%$ \\
\hline Rangking 8 & Kriteria Desain (DN) & $6,011 \%$ \\
\hline Rangking 9 & Kriteria Faktor Politik (FP) & $4,738 \%$ \\
\hline Rangking 10 & Kriteria Klausal Kontrak (KK) & $3,605 \%$ \\
\hline & Total: & $100,609 \%$ \\
\hline
\end{tabular}

\section{Tabel 18}

Daftar Rangking Kriteria untuk Proyek TOL NILAI RANGKING KRITERIA

\begin{tabular}{ccc}
\hline Rangking & Kriteria & Bobot \\
\hline Rangking 1 & Kriteria Finansial (FL) & $24,252 \%$ \\
\hline Rangking 2 & Kriteria Kebijakan Pemerintah (KP) & $11,713 \%$ \\
\hline Rangking 3 & Kriteria Tujuan Proyek (TP) & $11,511 \%$ \\
\hline Rangking 4 & Kriteria Sumber Daya (SD) & $11,050 \%$ \\
\hline Rangking 5 & Kriteria Teknis (TK) & $10,773 \%$ \\
\hline Rangking 6 & Kriteria Lokasi (LO) & $8,024 \%$ \\
\hline Rangking 7 & Kriteria Keuangan (KU) & $7,629 \%$ \\
\hline Rangking 8 & Kriteria Faktor Politik (FP) & $6,956 \%$ \\
\hline Rangking 9 & Kriteria Desain (DN) & $4,830 \%$ \\
\hline Rangking 10 & Kriteria Klausal Kontrak (KK) & $3,261 \%$ \\
\hline & Total: & $100,000 \%$ \\
\hline
\end{tabular}


Terlihat kriteria utama menjadi dua kelompok yaitu kriteria 1-5 kelompok pertama dan kriteria 6-10 kelompok kedua dengan perbedaan bobot yang mencolok, tetapi terdapat hasil yang sangat mengejutkan untuk "Kriteria Finansial" yaitu bahwa kriteria ini sangat berpengaruh terhadap seluruh proyek yang diteliti dan menempati peringkat pertama dengan perbedaan bobot yang jauh dari peringkat dibawahnya.

Berdasarkan hasil analisa didapatkan rangking prioritas dari lima proyek infrastruktur dengan skema KPBU seperti ditunjukkan pada Tabel 19.

Tabel 19

Rangking Prioritas Proyek Infrastruktur NILAI AKHIR RANGKING PRIORITAS

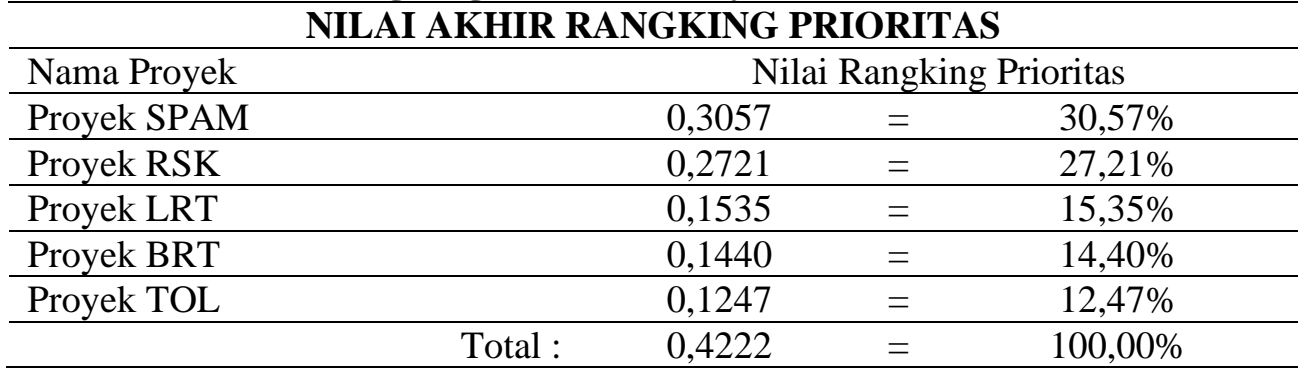

Proyek SPAM mendapatkan peringkat tertinggi dengan bobot sebesar $30,57 \%$, hasil studi ini membantu stakeholder dalam tahap prastudi kelayakan dan juga menentukan prioritas proyek mana yang akan dilaksanakan.

Setelah meninjau dan menganalisis metode pengambilan keputusan ini, AHP dapat dimanfaatkan untuk menetapkan tingkat prioritas proyek dengan mempertimbangkan kriteria utama dan pengaruh sub kriteria terhadap proyek. Penelitian ini dapat diperluas tidak hanya pada bidang infrastruktur dan konstruksi saja tetapi juga untuk berbagai permasalahan yang berbeda dengan kriteria dan sub kriteria yang lebih beragam dengan narasumber yang lebih banyak, diharapkan dengan memperluas data peneltian diharapkan hasil yang diperoleh lebih realistis.

\section{Kesimpulan}

Berdasarkan hasil analisis dan pembahasan pada bab-bab sebelumnya, diperoleh kesimpulan bahwa penggunaan AHP juga dapat dilakukan dalam suatu skenario multi kriteria dan multi proyek, dalam penelitian ini diambil lima proyek, yaitu Proyek Rumah Sakit (RSK), Proyek Sistem Penyediaan Air Minum (SPAM), Proyek Kereta Api Ringan/Light Rail Transit (LRT), Proyek Bus Rapid Transit (BRT) dan Proyek Tax On Location (TOL).

Pemilihan proyek yang berbeda-beda dilakukan untuk menunjukkan bahwa penggunaan AHP tidak terbatas pada proyek-proyek yang sama saja atau pada kasus yang sama, penentuan hierarki pada level pertama dan level kedua sangat menentukan dalam proses pengambilan keputusan multi kriteria dan pemilihan narasumber yang sesuai dengan kasus yang sedang diteliti juga menjadi sangat menentukanserta data yang dipergunakan juga sangat dominan mempengaruhi. 
Herri Suryadi Samosir, A. Perwira Mulia Tarigan dan Fahmi Fahmi

Hasil dari perhitungan nilai rangking masing-masing kriteria terhadap seluruh proyek yang ditinjau menunjukkan dari 10 kriteria yang ditetapkan terdapat persamaan yaitu pada Kriteria Finansial (FL) dengan bobot di atas $20 \%$ pada seluruh proyek, diartikan bahwa Kriteria Finansial sangat mempengaruhi pengambilan keputusan dan Kriteria Klausul Kontrak (KK) dengan bobot di bawah 5\% pada seluruh proyek, diartikan bahwa Kriteria Klausul Kontrak (KK) sangat tidak mempengaruhi pengambilan keputusan, untuk kriteria lainnya terdapat perbedaan nilai bobot pada masing-masing proyek yang ditinjau. 


\section{BIBLIOGRAFI}

Afiyanti, Yati. (2008). diskusi kelompok terfokus sebagai metode pengumpulan data penelitian kualitatif. Jurnal Keperawatan Indonesia, 12(1), 58-62. Google Scholar

Darmanto, Eko, Latifah, Noor, \& Susanti, Nanik. (2014). Penerapan metode AHP (Analythic Hierarchy Process) untuk menentukan kualitas gula tumbu. Simetris: Jurnal Teknik Mesin, Elektro Dan Ilmu Komputer, 5(1), 75-82. Google Scholar

Delmon, Jeffrey. (2010). Understanding options for public-private partnerships in infrastructure: sorting out the forest from the trees: BOT, DBFO, DCMF, concession, lease... The World Bank. Google Scholar

Nandi, Soumya, Paul, Soumik, \& Phadtare, Milind. (2011). An AHP-based construction project selection method. Decision (0304-0941), 38(1). Google Scholar

Noorzai, Esmatullah, Jafari, K. Gharouni, Heshmatnezhad, Rouhallah, \& Vahedi, Babak. (2016). Implementing AHP approach to select an appropriate financing method for PPP highway projects in Iran. International Journal of Structural and Civil Engineering Research, 3(1), 67-73. Google Scholar

Saaty, Thomas L. (1986). Axiomatic foundation of the analytic hierarchy process. Management Science, 32(7), 841-855. Google Scholar

Saaty, Thomas L. (1990). How to make a decision: the analytic hierarchy process. European Journal of Operational Research, 48(1), 9-26. Google Scholar

Saaty, Thomas L. (2008). Decision making with the analytic hierarchy process. International Journal of Services Sciences, 1(1), 83-98. Google Scholar

Samosir, Herri Suryadi. (2020). Studi Prioritas Pembiayaan Pembangunan Infrastruktur dengan Skema KPBU Menggunakan AHP. Google Scholar

Sasongko, Aji, Astuti, Indah Fitri, \& Maharani, Septya. (2017). Pemilihan karyawan baru dengan metode AHP (Analytic Hierarchy Process). Google Scholar

Schwab, Klaus. (2018). The global competitiveness report 2018. World Economic Forum, 671. Google Scholar

\section{Copyright holder:}

Herry Suryadi Samosir, A. Perwira Mulia Tarigan dan Fahmi (2021)

First publication right :

Journal Syntax Literate

This article is licensed under:

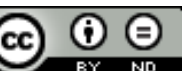

